\title{
Impact Properties of Acrylic Denture Base Resin
} Part 3 Impact Properties of Cross-linked Polymers

\section{Jun-ichi OKU}

Department of Dental Materials Science, Kagoshima University Dental School, 1208-1 Usuki, Kagoshima 890, Japan

Received on July 29, 1989

Accepted on October 12, 1989

The impact properties in acrylic denture base resins cross-linked using 6 diacrylates, such as ethylene glycol dimethacrylate (EDMA) and $p$-divinyl benzene (DVB), were investigated and discussed. In addition, the creep characteristics of these cross-linked resins were examined and related with their impact characteristics. From these results, it was seen that both characteristics deteriorated with an increase in the diacrylate concentration from $2 \mathrm{~mol} \%$ to $10 \mathrm{~mol} \%$. On the other hand, an increase in the repeated number (n) of ($\left.\mathrm{CH}_{2}-\mathrm{CH}_{2}-\mathrm{O}-\right)_{\mathrm{n}}$ promoted a flexibility in the materials which resulted in a higher impact strength and toughness. But, there was no a significant difference in the resilience of these materials.

Key words : Acrylic resin, Cross-linking agent, Impact property

\section{INTRODUCTION}

Numerous studies have reported the impact properties of acrylic denture base resins. In these studies, however, all tests have been performed at a higher hitting speed as compared with chewing speed. It is considered that the flexibility of the molecular chain sufficiently affects the impact strength of the materials for the relatively slow hitting speed characteristic of chewing ${ }^{1-5}$.

On the other hand, in clinical use, it is preferable for the denture base to exhibit a high impact resistance against the impact forces associated with chewing ${ }^{6-8)}$. In commercial denture base materials, therefore, several diacrylates have been added to methyl metha. crylate for this purpose?.

The purpose of this investigation is to examine the impact properties of cross-linked polymers and the creep characteristics of such materials.

\section{MATERIALS AND METHODS}

\section{Materials}

The materials used in this investigation along with the code, composition of materials, and curing conditions are presented in Table 1 . Six diacrylates which contain two polymerizable bonds were used as a cross-linking agent, and benzoil peroxide ( $0.5 \%$ of base comonomer weight) was incorporated in the base comonomer. The structural formula of materials used are as follows : 
Table 1 Composition of materials used and curing conditions

\begin{tabular}{|c|c|c|c|c|c|}
\hline \multirow{2}{*}{ Code } & \multirow{2}{*}{$\begin{array}{l}\text { Diacrylate } \\
\text { added to } \mathrm{MMA}^{\prime \prime}\end{array}$} & \multicolumn{2}{|c|}{ Comonomer (mol\%) } & \multirow{2}{*}{$\begin{array}{l}\text { PMMA }^{21} / \text { comonomer } \\
\text { ratio }\end{array}$} & \multirow{2}{*}{$\begin{array}{l}\text { Curing } \\
\text { condition }\end{array}$} \\
\hline & & $\overline{\mathrm{MMA}}$ & Diacrylate & & \\
\hline A & none & 100 & 0 & $2 / 1$ & I \\
\hline $\mathrm{B}_{1}$ & & 98 & 2 & $2 / 1$ & II \\
\hline $\mathrm{B}_{2}$ & EDMA $^{3)}$ & 95 & 5 & $2 / 1$ & II \\
\hline $\mathrm{B}_{3}$ & & 90 & 10 & $2 / 1$ & II \\
\hline $\mathrm{C}_{1}$ & & 98 & 2 & $2 / 1$ & II \\
\hline $\mathrm{C}_{2}$ & Di-EDMA ${ }^{4}$ & 95 & 5 & $2 / 1$ & II \\
\hline $\mathrm{C}_{3}$ & & 90 & 10 & $2 / 1$ & II \\
\hline $\mathrm{D}_{1}$ & & 98 & 2 & $2 / 1$ & II \\
\hline $\mathrm{D}_{2}$ & Tri-EDMA $^{5)}$ & 95 & 5 & $2 / 1$ & II \\
\hline $\mathrm{D}_{3}$ & & 90 & 10 & $2 / 1$ & II \\
\hline$E_{1}$ & & 98 & 2 & $2 / 1$ & II \\
\hline $\mathrm{E}_{2}$ & Tetra-EDMA ${ }^{6)}$ & 95 & 5 & $2 / 1$ & II \\
\hline $\mathrm{E}_{3}$ & & 90 & 10 & $2 / 1$ & II \\
\hline$F_{1}$ & & 98 & 2 & $2 / 1$ & II \\
\hline $\mathrm{F}_{2}$ & $\mathrm{DVB}^{7}$ & 95 & 5 & $2 / 1$ & II \\
\hline$F_{3}$ & & 90 & 10 & $2 / 1$ & II \\
\hline $\mathrm{G}_{1}$ & & 98 & 2 & $2 / 1$ & II \\
\hline $\mathrm{G}_{2}$ & BPDMA $^{8)}$ & 95 & 5 & $2 / 1$ & II \\
\hline $\mathrm{G}_{3}$ & & 90 & 10 & $2 / 1$ & II \\
\hline
\end{tabular}

I : Raising the temperature according to dental curing techniques and keeping it for $1 \mathrm{~h}$ at $100^{\circ} \mathrm{C}$ in an atmosphere of $\mathrm{N}_{2}$ gas $\left(3 \mathrm{kgf} / \mathrm{cm}^{2}\right)$

Il : Raising the temperature according to dental curing techniques and keeping it for $1.5 \mathrm{~h}$ at $100^{\circ} \mathrm{C}$ in an atmosphere of $\mathrm{N}_{2}$ gas $\left(3 \mathrm{kgf} / \mathrm{cm}^{2}\right)$

1) MMA : Methyl methacrylate (lst class reagent)

2) PMMA : Polymethyl methacrylate (Acricon)

3) EDMA : Ethylene glycol dimethacrylate (1st class reagent)

4) Di-EDMA : Di-ethylene glycol dimethacrylate (1st class reagent)

5) Tri-EDMA : Tri-ethylene glycol dimethacrylate (lst class reagent)

6) Tetra-EDMA : Tetra-ethylene glycol dimethacrylate (1st class reagent)

7) DVB : p-divinyl benzene (1st class reagent)

8) BPDMA : Bisphenol-A dimethacrylatc (lst class reagent)<smiles>C=C(C)C(=O)OC</smiles>

Methyl methacrylate (MMA)<smiles>C=C(C)C(=O)OCCOC(=O)C(=C)C</smiles> 
$\mathrm{n}=1$, Ethylene glycol dimethacrylate (EDMA)

$\mathrm{n}=2$, Di-ethylene glycol dimethacrylate (Di-EDMA)

$\mathrm{n}=3$, Tri-ethylene glycol dimethacrylate (Tri-EDMA)

$\mathrm{n}=4$, Tetra-ethylene glycol dimethacrylate (Tetra-EDMA)<smiles>C=Cc1ccc(C=C)cc1</smiles>

$p$-divinyl benzene (DVB)<smiles>C=C(C)C(=O)Oc1ccc(C(C)(C)c2ccc(OC(=O)C(=C)C)cc2)cc1</smiles>

Bisphenol-A dimethacrylate (BPDMA)

All specimens were polymerized in a PTFE mold $(3.1 \times 3.1 \times 60 \mathrm{~mm})$ according to the curing technique described in previous reports ${ }^{11 .}{ }^{12}$. After polymerization, the specimens were classified into the following 2 groups.

(1) Specimen stored in a desiccator $\left(23^{\circ} \mathrm{C}\right)$ for 1 week after polymerization (for use in the impact test and creep test in air).

(2) Specimen stored in water $\left(37^{\circ} \mathrm{C}\right)$ for 3 weeks after polymerization (for use in the impact test in air and the creep test in water).

A V-notch was incised on the smooth surface of each impact test specimen immediately before testing, using a double angle $\left(45^{\circ}\right)$ convex cutter. The depth of each V-notch was $20 \%$ of the original specimen thickness. The specimens used in this investigation were $3 \mathrm{~mm}$ in thickness, $3 \mathrm{~mm}$ in width, and $40 \mathrm{~mm}$ in length. The specimen supporting span was $30 \mathrm{~mm}$ in length for the impact test and $15 \mathrm{~mm}$ in length for the creep test.

Methods

\section{1) Impact test ${ }^{10-12)}$}

The apparatus used in this investigation was the impact testing machine described in previous reports ${ }^{11,12}$. All impact tests were carried out in air $\left(\right.$ at $\left.23^{\circ} \mathrm{C}\right)$ with a hitting speed of $13.5 \mathrm{~cm} / \mathrm{s}$.

2) Creep test ${ }^{13-15}$

The creep test were performed using a modification of the transverse testing machine described in the Japanese Industrial Standard (JIS T-6051). All creep tests were carried out in air and in water (at $23^{\circ} \mathrm{C}$ ) by adding the static load $(3.5 \mathrm{kgf}$ ) for $120 \mathrm{~min}$ to the center of a specimen, and the creep compliance $J(t)$ was calculated from the resulting creep curve.

3) Measurement of water absorption ${ }^{16)}$

Seven pillar shaped specimens $(3.0 \times 3.0 \times 58.0 \mathrm{~mm})$ were accurately weighed and immediately immersed in distilled water for 3 weeks at $37^{\circ} \mathrm{C}$. Water absorption was determined by calculating the difference in a specimen's weight before and after immersion in water. 


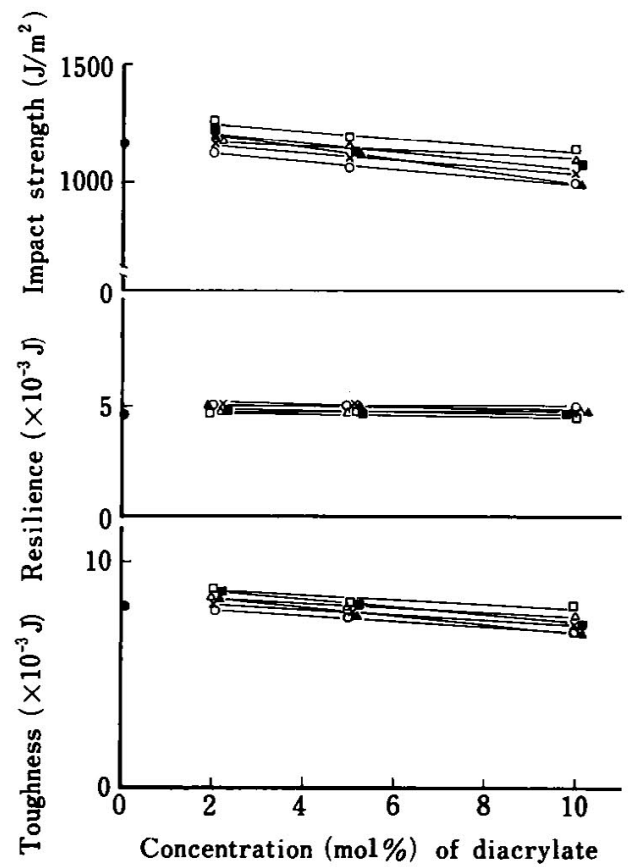

Fig. 1 Variation in impact strength, resilience and toughness with concentration (mol\%) of diacrylate for notched specimen $(3 \mathrm{~mm} \times 3 \mathrm{~mm} \times 60 \mathrm{~mm})$ of crosslinked resins $(l=30 \mathrm{~mm})$. All specimens were stored in a desiccator $\left(23^{\circ} \mathrm{C}\right)$ for 1 week after the polymerization.

. $A ; O, B_{1,2,3} ; \times, C_{1,2,3} ; \Delta, D_{1,2,3} ; \square, E_{1,2,3} ; \Delta, F_{1,2,3} ; \square, G_{1}, 2,3$.

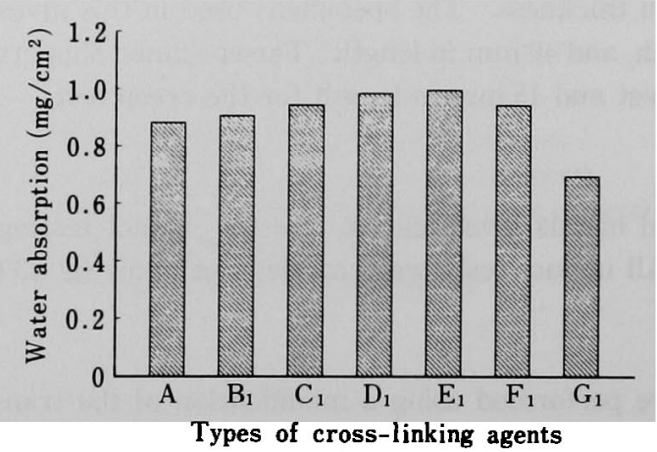

Fig. 2 Variation of water absorption of cross-linked polymer (added $2 \mathrm{~mol} \%$ diacrylate to base MMA monomer) against cross-linking agents. All specimens were soaked into distilled water $\left(37^{\circ} \mathrm{C}\right)$ for 3 weeks after polymerization.

\section{RESULTS AND DISCUSSION}

The variation, in the impact strength, resilience and toughness with the concentration of diacrylates is shown in Fig. 1. The impact strength and toughness for group (1) specimens, 


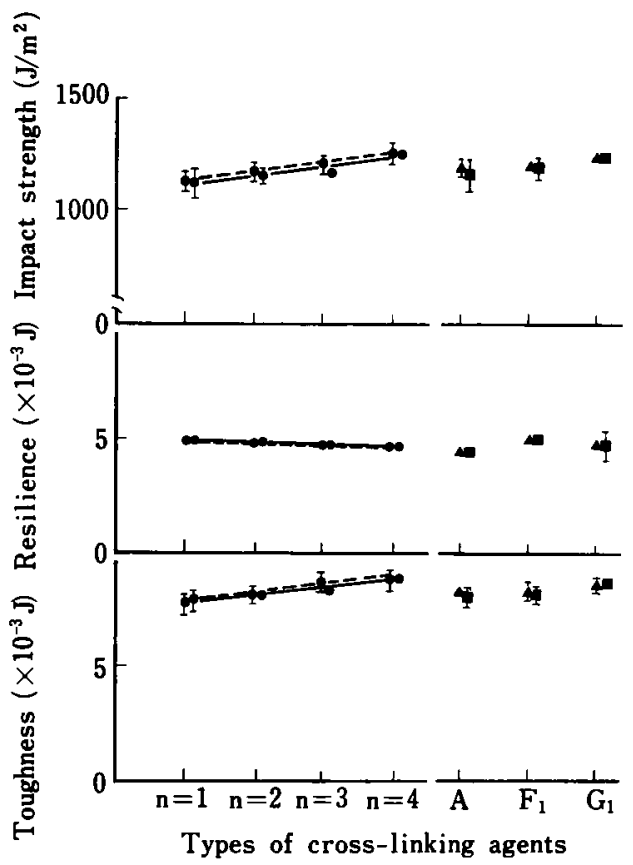

Fig. 3 Variation in impact strength, resilience and toughness of cross-linked polymer (added $2 \mathrm{~mol} \%$ diacrylate to base MMA monomer) against types of crosslinking agents. Solid line shows the specimen tested in air $\left(23^{\circ} \mathrm{C}\right)$. Broken line shows the specimen soaked into water $\left(37^{\circ} \mathrm{C}\right)$ for 3 weeks after polymerization and the specimen tested in air $\left(23^{\circ} \mathrm{C}\right)$.

. $n=1\left(B_{1}\right), n=2\left(C_{1}\right), n=3\left(D_{1}\right), n=4\left(E_{1}\right) ; \square$, for dried specimen $\left(A, F_{1}\right.$ and $\left.G_{1}\right)$;

$\Delta$, water absorptive specimen $\left(A, F_{1}\right.$ and $\left.G_{1}\right)$.

diminished slightly with an increase in the diacrylate concentration of methyl methacrylate, and they increased with an increase in the repeated number (n) in $\left(-\mathrm{CH}_{2}-\mathrm{CH}_{2}-\mathrm{O}-\right)_{\pi}$ in the EDMA groups. On the other hand, the resilience was constant $\left\{(4.8 \pm 0.2) \times 10^{-3} \mathrm{~J}\right\}$, independent of the concentration of the diacrylate.

These results indicate that an increase in the cross-linking reaction has diminished the flowability of polymer, which has resulted in a reduction of impact strength.

The maximum values of the impact strength for the 6 group materials ( $B$ to $G$ ) were determined for specimens in a diacrylate concentration of $2 \mathrm{~mol} \%$. All measurements of water absorption and creep were taken using these specimens.

The water absorption values for the specimens of code numbers $A, B_{1}, C_{1}, D_{1}, E_{1}, F_{1}$, and $\mathrm{G}_{1}$ are shown in Fig. 2. It is apparent that the water absorption increased with an increase in the repeated number (n) in the $\left(-\mathrm{CH}_{2}-\mathrm{CH}_{2}-\mathrm{O}-\right)_{n}$ group in the ethylene glycol dimethacrylate monomer. Figure 3 shows the impact properties for the dry specimens and water absorbed specimens. There was almost no recognizable difference between them. These results indicate that impact properties will be affected significantly by an increase in $n$, but for speeds seen in chewing, they will not be affected very much by the moisture content 


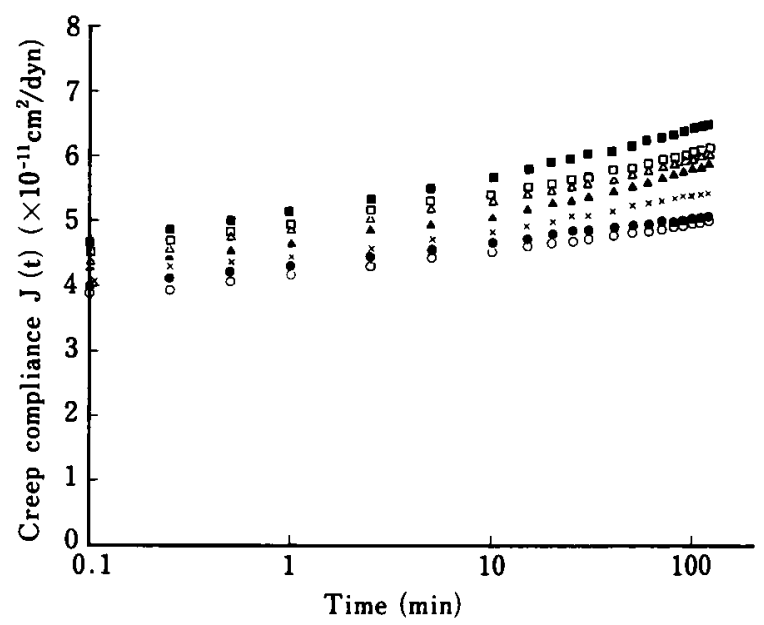

Fig. 4 Variation of creep compliance $J(t)$ with time for specimen stored in desiccator $\left(23^{\circ} \mathrm{C}\right)$ for 1 week after polymerization and tested in air $\left(23^{\circ} \mathrm{C}\right)$.

- $A ; O, B_{1} ; \times, C_{1} ; \Delta, D_{1} ; \square, E_{1} ; \Delta, F_{1} ; \square, G_{1}$.

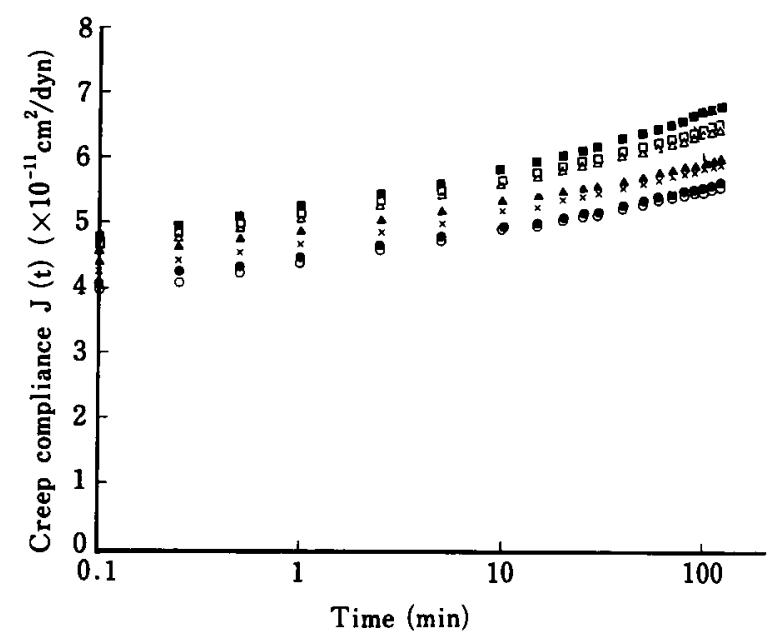

Fig. 5 Variation of creep compliance $J(t)$ with time for specimen soaked in water $\left(37^{\circ} \mathrm{C}\right)$ for 3 weeks after polymerization and tested in water $\left(23^{\circ} \mathrm{C}\right)$.

$\mathrm{A} ; \mathrm{O}, \mathrm{B}_{1} ; \times, \mathrm{C}_{1} ; \triangle, \mathrm{D}_{1} ; \square, \mathrm{E}_{1} ; \Delta, \mathrm{F}_{1} ; \mathbf{\square}, \mathrm{G}_{1}$.

absorbed into the specimen. Figures 4 and 5 shows how the creep compliance J(t) varies with time from the start of measurement. Since $J(t)$ is defined as the inverse number of the elastic modulus, the increase in values of $\mathrm{J}(\mathrm{t})$ means that the flowability of materials is large. From these two figures, it is seen that each material flows considerably with time under a load, and the flowability slightly rises with an increase in $\mathrm{n}$.

This tendency was also observed in the polymer containing benzene rings, and its flowability progressed with an increase in the number of benzene rings in the diacrylates. The 
Table 2 Comparison of resilience obtained by impact test $\left(23^{\circ} \mathrm{C}\right)$ and $1 / \mathrm{J}(0.1)$ obtained by creep test $\left(23^{\circ} \mathrm{C}\right)$

\begin{tabular}{|c|c|c|c|c|c|}
\hline \multirow{2}{*}{ Code } & \multirow{2}{*}{$\begin{array}{l}\text { Diacrylate } \\
\text { added to } \\
\text { MMA }\end{array}$} & \multicolumn{2}{|c|}{ Resilience $\left(\times 10^{-3} \mathrm{~J}\right)$} & \multicolumn{2}{|c|}{$1 / \mathrm{J}(0.1)\left(\times 10^{10} \mathrm{dyn} / \mathrm{cm}^{2}\right)$} \\
\hline & & $\begin{array}{l}\text { Dried } \\
\quad \text { specimen }\end{array}$ & $\begin{array}{l}\text { Wet specimen } \\
\text { (tested in air) }\end{array}$ & $\begin{array}{l}\text { Dried } \\
\text { specimen }\end{array}$ & $\begin{array}{l}\text { Wet specimen } \\
\text { (tested in water) }\end{array}$ \\
\hline A & none & $4.57(0.188)$ & $4.55(0.148)$ & 2.50 & 2.47 \\
\hline $\mathrm{B}_{1}$ & EDMA & $5.00(0.200)$ & $4.90(0.164)$ & 2.57 & 2.51 \\
\hline $\mathrm{C}_{1}$ & Di-EDMA & $4.88(0.144)$ & $4.79(0.247)$ & 2.48 & 2.36 \\
\hline $\mathrm{D}_{1}$ & Tri-EDMA & $4.73(0.0968)$ & $4.79(0.190)$ & 2.29 & 2.20 \\
\hline$E_{1}$ & Tetra-EDMA & $4.69(0.107)$ & $4.66(0.0991)$ & 2.20 & 2.14 \\
\hline$F_{1}$ & DVB & $4.99(0.118)$ & $5.00(0.149)$ & 2.34 & 2.28 \\
\hline $\mathrm{G}_{1}$ & BPDMA & $4.76(0.0715)$ & $4.76(0.149)$ & 2.17 & 2.12 \\
\hline
\end{tabular}

individual values for resilience and $1 / \mathrm{J}(0.1)^{*}$ are listed in Table 2. It would appear that the valves of resilience and $1 / \mathrm{J}(0.1)$ for the dried specimens and wet specimens were in good agreement. This result indicates that water absorbed by the specimen does not significantly affect the mechanical properties of the specimen.

In general, it has been reported that in many cases, the benzene rings which exist in the main molecular chains, contribute exceedingly to improvements in hardness and in other mechanical properties of a material. In this investigation, however, the impact properties (impact strength, resilience and toughness) and creep characteristics (creep compliance and flowability) for $F_{1-3}$ and $G_{1-3}$ were almost equivalent to those of the EDMA series $\left(B_{1-3}\right.$ to $\left.E_{1-3}\right)$.

\section{CONCLUSIONS}

Impact and creep tests on cross-linked polymethyl methacrylate materials were carried out.

(1) The impact strength and toughness of the cross-linked polymer diminished slightly with an increase in the concentration of the individual cross-linking agents.

(2) The increase of $\mathrm{n}$ in the $\left(-\mathrm{CH}_{2}-\mathrm{CH}_{2}-\mathrm{O}-\right)_{n}$ group slightly improved the impact property of the material.

(3) From the differences in the values of $\mathrm{J}(0.1)$ and $\mathrm{J}(120)$ in the creep test, it was seen that the flowability of the materials slightly increased. However, in the case of materials that had absorbed water, the values of $1 / \mathrm{J}(0.1)$ for the dried specimens and wet specimens were in good agreement.

(4) Though water absorbed into a specimen acts generally as a plasticizer, it is possible that in test speeds seen in chewing, the impact properties of the materials will not be affected by the absorbed water.

\footnotetext{
* $\mathrm{J}(0.1)$ is the creep compliance at $0.1 \mathrm{~min}$ from the start of measurement.
} 


\section{ACKNOWLEDGMENT}

The author is deeply grateful to Prof. Katsuichiro Inoue for his invaluable advice. The author also would like to thank the staff of the Department of Dental Materials Science of Kagoshima University Dental School for their helpful cooperation.

\section{REFERENCES}

1) Price, C.A.: The effect of cross-linking agents on the impact resistance of a linear poly (methyl methacrylate) denture-base polymer, $J$ Dent Res 65(7): 987-992, 1986.

2) Price, C. A. and Earnshaw, R. Impact testing of a polysulphone denture base polymer, Aust Dent J 29 : 398-403, 1984.

3) Rodford, R.: The development of high impact strength denture-base materials, $J$ Dent 14: 214-217, 1986.

4) Berry, J. P.: Surface characteristics of fractured poly (methyl methacrylate), Nature 185: 91-92, 1960.

5) Barsby, M. J. and Braden, M. : Visco-elastic properties of pour (fluid) denture base resins, $J$ Dent Res 60(2): 146-148, 1981.

6) Hargreaves, A.S.: The prevalence of fractured dentures, Brit Dent J 126: 451-455, 1969.

7) Finger, W.: Untersuchungen zur dynamischen Elastizităt und zur inneren Dămpfung von Prothesenkunststoffen, Dtsch zahndrztl $Z$ 31: 553-556, 1976.

8) Finger, W.: Mechanisch-dynamische Eigenschaften von Prothesen-Kunststoffen, Dtsch zahnärztl $Z 30$ : 665-671, 1975.

9) Hill, R.G.: The crosslinking agent ethylene glycol dimethacrylate content of the currently available acrylic denture base resins, $J$ Dent Res 60(3): 725-726, 1981.

10) Jones, P. A., Wilson, H. J. and Osborne, J. : Impact properties of dental materials, Brit Dent J129 : 565 $-570,1970$.

11) Oku, J. : Impact properties of acrylic denture base resin. Part $1 \mathrm{~A}$ new method for determination of impact properties, Dent Mater J 7(2): 166-173, 1988.

12) Oku, J.: Impact properties of acrylic denture base resin. Part 2 Effect of temperature and residual monomer on impact characteristics, Dent Mater $J$ (in press)

13) Inoue, K.: Fundamental studies on viscoelasticity of polymethyl methacrylate polymerized by monomer-polymer technique, $J$ Kyushu Dent Soc 25(5) : 443-464, 1972.

14) Papadogianis, Y., Boyer, D. B. and Lakes, R. S. : Creep of conventional and microfilled dental composites, $J$ Biomed Mater Res 18: 15-24, 1984.

15) Ferracane, J. L., Matsumoto, H. and Okabe, T.: Time-dependent deformation of composite resinsCompositional considerations, $J$ Dent Res 64(11): 1332-1336, 1985.

16) Braden, M.: The absorption of water by acrylic resins and other materials, $J$ Prosthet Dent 14(2) : 307 $-316,1964$. 


\title{
快削性セラミックスの歯科的応用に関する研究（第 1 報）色彩学的検討
}

\author{
平 雅之*, 若狭邦男", 山木昌雄", 田中伸征 ${ }^{* *}$, 新谷英章** \\ 広島大学雨学部歯科理工学諈座 \\ **広島大学歯学部歯科保存学第一講座
}

\begin{abstract}
切削加工が容易な快削性セラミックスの加工性の原理 の一つは, へき開性を有する結晶を素材内部に分散させ 加工時に発生したクラックが結晶のへき開性により進展 を止められる機桡を利用したものである。歯科領域にお いても最近 CAD-CAMによる補綴物製作の試みがなさ れている。本報ては，快削性セラミックスの歯科応用に ついての基礎的研究の一環として，8種類の市販快削性 セラミックスとVitaの焼付陶材用 shade guideを用い
\end{abstract}

て色彩色差計による色彩学的検討を行なった。 その結果, 長石陶材系の Vita shade guideに比較し て，いずれの快削性セラミックスも強い不透明感を与え る白色を呈することが明らかとなった。今後，産業用に 開発された快削性セラミックスを改良して㧘冠修復材料 として利用するためには，母相と分散相からなる微練構 造を変化させ照度 (L*) を大幅に下げる必要のあること が示唆された。

\section{アクリル系義歯床用レジンの衝撃特性}

\section{一第 3 報一 架橋ポリマーの耐衝撃性}

\author{
奥 淳一 \\ 鹿児島大学珤学部歯科理工学諈座
}

6 種類の架橋剤を用いて, 加熱重合したアクリル系義

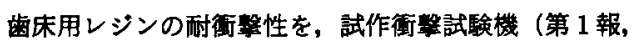
第 2 報）を用いて調へた。またこのレジンのクリープ 挙動, 吸水性を調へ, 衝擊特性值（衡擊強さ・レジリエ ンス・勒性)との関係を検討した。メタクリル酸メチル モノマーに対する各架橋用漫度 ( $2 \mathrm{~mol} \%$ から $10 \mathrm{~mol} \%$ 䈯囲で）が高くなるにつれて，重合体の衡撃強さ・鞄性 值はわずかに低下する傾向を示したが，レジリエンスに
は変化がみられず, $(4.8 \pm 0.2) \times 10^{-3} \mathrm{~J}$ の安定した值を 示した。エチレングリコールジメタクリレート系 (EDMA, Di-EDMA, Tri-EDMA, Tetra-EDMA) モ ノマー中の 2 官能基間の鎖 $\left(-\mathrm{CH}_{2}-\mathrm{CH}_{2}-\mathrm{O}^{-}\right)_{n}$ において, 反復度数 (n) の増加にしたがって衙擊強さおよび勒性值 は幾分上㫒する傾向を示した。また，架橋郕濃度 $2 \mathrm{~mol} \%$ の試料間では，反復度数（n)の増加にともなってクリー プコンプライアンス, 吸水率は增加した。

\section{人歯牙象牙質およびエナメル質のねじりにおける動的弾性率}

\section{有川裕之 \\ 鹿児島大学歯学部歯科理工学諈座}

ねじれ自由減衰型粘弾性测定装置をもちいて人匊牙象 牙實およびエナメル筫の野的弾性率を測定した。

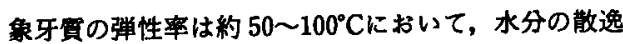
によると思われるわずかな増加がみられた。損失率は約 $75^{\circ} \mathrm{C}$ 付近にピークが瞄察された。一方，エナメル賢では 温度による弾性率および損失率の変化はほとんどなく非 常に安定している。60 個の崡冠部象牙質試料のずり弾性 率の平均は $8.70 \times 10^{10} \mathrm{dyn} / \mathrm{cm}^{2}$ であった。同一齿牙にお
ける畨冠部象牙質と菡根部象牙質の值に明確な差異はみ られなかった。40個のエナメル質試料の值の平均は 3. $10 \times 10^{11} \mathrm{dyn} / \mathrm{cm}^{2}$ であった。エナメル䝯は象牙䝯に比べ 約 3〜 5 倍高い弾性率を示し,これは理論值とほほ一致 した。またエナメル賽の損失率は象牙實に比べ低い值を 示した。

象牙質,エナメル質ともに弾性率の值と歯牙の履歴(性 別, 年齢, 部位)との間に明確な相関はみられなかった。 